\title{
MENGUJI SENSITIVITAS RASIONALISASI PADA KEPUTUSAN MELAKUKAN KORUPSI DI INSTANSI PELAYANAN PUBLIK
}

\section{RATIONALIZATION SENSITIVITY TEST ON DECISION TO CORRUPT IN PUBLIC SECTOR}

\author{
Johann Tarru \\ PKP2A II Lembaga Administrasi Negara \\ jtmada@gmail.com
}

\begin{abstract}
Abstrak
Merujuk pada akuntansi forensik, cara terbaik memberantas korupsi yaitu mengenali dengan baik latar belakang dibalik perilaku korup tersebut. Sektor publik di Indonesia dikejutkan dengan corruption perceptions index yang dikeluarkan Transparency International diawal tahun 2018, menunjukkan adanya perlambatan upaya pemberantasan korupsi tanah air. Institusi pemerintah sebagai penanggung jawab utama sektor publik mendapatkan sorotan dari masyarakat terkait capaian ini. Oleh karena itu, semangat memberantas korupsi perlu digelorakan. Titik awalnya dengan mencoba membedah fraud triangle theory guna mengalirkannya pada sebuah strategi pencegahan korupsi yang tepat bagi instansi sektor publik. Penelitian ini bermaksud untuk menguji sensitivitas 3 variabel utama, yakni: pressure, rationalization, dan opportunity dalam upaya pencegahan korupsi. Sampel yang digunakan yaitu 47 orang tenaga medis pada Rumah Sakit Umum Daerah Kabupaten Polewali Mandar di Provinsi Sulawesi Barat. Data yang masuk dikompilasi kemudian dianalisis dengan menggunakan path analysis. Hasil analisis menunjukkan bahwa rationalization merupakan variabel yang paling efektif dalam upaya pencegahan korupsi di instansi publik.
\end{abstract}

Kata Kunci: pressure, rationalization, opportunity, pencegahan korupsi, fraud triangle theory.

\begin{abstract}
Referring to forensic accounting, the best way to combat corruption is recognizing the background of the corrupt behavior. Public sector in Indonesia were shocked by Corruption Perceptions Index issued by Transparency International early 2018 which showed a decceleration on corruption eradication efforts. Government institutions as stakeholders in charge of the public sector get the
\end{abstract}


spotlight from the public related to it. Therefore, the spirit to eradicate corruption need to be proliferated particularly by dissecting the fraud triangle theory in order to find suitable corruption prevention strategy for public sector agencies. This research intends to test the sensitivity of the 3 main variables: pressure, rationalization, and opportunity in the corruption prevention efforts. The sample used i.e. 47 people medical personnel at the Regional General Hospital Polewali Mandar Regency in West Sulawesi province. All collected data is compiled and then analyzed using path analysis. The results of the analysis showed that rationalization is the most effective variables in corruption prevention efforts in public agencies.

Kata Kunci: pressure, rationalization, opportunity, corruption prevention, fraud triangle theory.

\section{PENDAHULUAN}

Mengapa orang melakukan korupsi, padahal mereka tahu itu perbuatan yang tidak baik? Merupakan sebuah pertanyaan sederhana, menjawabnya mungkin saja ringan dibanding upaya untuk menghadirkannya secara nyata ditengahtengah masyarakat. Negara inipun membutuhkan upaya kolektif kebangsaan untuk mewujudnyatakannya.

Sebagaimana tercantum pada penjelasan atas UU No. 7 Tahun 2006 tentang Pengesahan United Nations Convention Against Corruption-2003, dikatakan bahwa korupsi merupakan ancaman terhadap prinsip-prinsip demokrasi, yang menjunjung tinggi transparansi, akuntabilitas, dan integritas, serta keamanan dan stabilitas bangsa Indonesia. Korupsi merupakan tindak pidana yang bersifat sistematik dan merugikan pembangunan berkelanjutan sehingga memerlukan langkah-Iangkah pencegahan dan pemberantasan yang bersifat menyeluruh, sistematis, dan berkesinambungan baik pada tingkat nasional maupun tingkat internasional. Inilah juga mengapa korupsi sering disebut sebagai extra ordinary crime.

Karena merupakan kejahatan yang luar biasa, inilah mengapa pada tahun sebelumnya dilahirkan UU No. 20 tahun 2001 sebagai perubahan atas UU No. 31 tahun 1999 tentang Pemberantasan Tindak Pidana Korupsi (KPK 2015: 9).

Upaya pemberantasan korupsi di Indonesia sebenarnya sudah dimulai sejak tahun 1957, pada saat dikeluarkannya Peraturan Militer PRT/PM/06/1957. Dalam perkembangannya dirasakan bahwa kehadiran regulasi saja tidak cukup efektif 
untuk memberantas korupsi, perlu dibentuk sebuah lembaga khusus. Oleh karenanya kemudian, Komisi Pemberantasan Korupsi pun lahir berdasarkan UU No. 30 tahun 2002, dengan amanah yang sangat besar untuk memberantas korupsi. KPK menjadi superbody karena kewenangannya yang luas dapat melakukan penyelidikan, penyidikan dan penuntutan terkait tindak pidana korupsi (Ali, M 2012: 225).

Tahun 2017, merupakan tahun prestasi Komisi Pemberantasan Korupsi (KPK) dalam melakukan operasi tangkap tangan (OTT). Sebagaimana dilansir pada situs resminya, www.kpk.go.id, tercatat ada sebanyak 19 OTT yang dilakukan. Jumlah yang belum pernah dicapai selama sejarah berdirinya institusi ini di tanah air. Sebagai pembanding tercatat pada tahun 2014 dan 2015 masing-masing sebanyak 5 OTT, kemudian meningkat ditahun 2016 sebanyak 17 OTT (detik.com, 30/11/2017).

Hanya saja prestasi tersebut belum sepenuhnya dirasakan memuaskan bagi upaya serius dalam memberantas korupsi jika hanya menyorot pada aspek penindakan saja. Menurut Abraham Samad, Indonesia merupakan negara dengan tingkat korupsi yang tinggi sehingga cara pemberantasannya harus dengan cara yang luar biasa, harus dilakukan secara komprehensif dimana dihulu dilakukan penindakan yang represif, ditengah dilakukan upaya pencegahan, dan dihilir diimplementasikan pendidikan karakter (detik.com, 11/12/2017).

Transparency International, sebuah lembaga swadaya masyarakat internasional yang mendedikasikan dirinya dalam upaya memerangi korupsi di dunia, sejak 1995 mengeluarkan sebuah indeks tahunan yang dinamakan corruption perceptions index (CPI) untuk mengukur persepsi masyarakat terkait korupsi pada sektor publik disebuah negara.

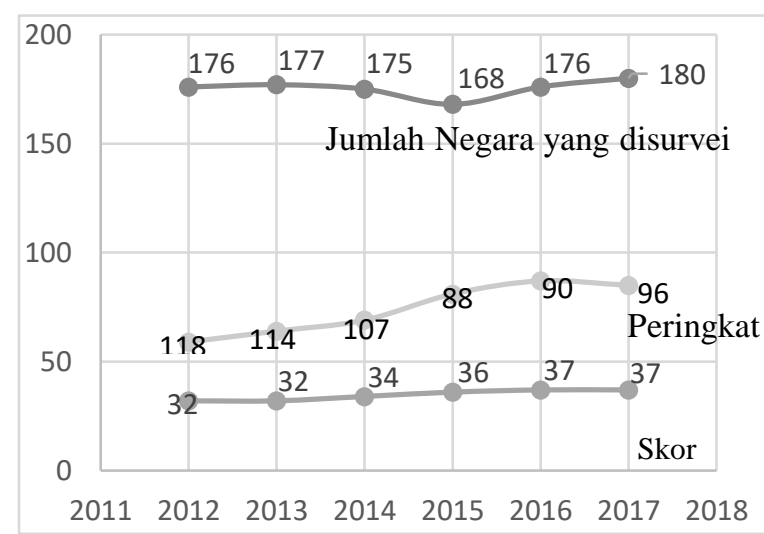

Gambar 1: Indonesia Corruption Perceptions Index (2012-2017)

Sebagaimana tampak pada tabel CPI, Indonesia memiliki skor yang tidak mengalami banyak perubahan yakni pada kisaran 32 hingga 37 selama periode 20122017. Trennya menunjukkan perubahan yang positif namun relatif lambat.

Hasil yang sama juga tampak pada indikator peringkat, dimana terlihat tren peningkatan di tahun 2013 hingga 2015 
namun mulai mendatar khususnya pada tahun 2016 dan 2017. Belajar dari hasil indeks persepsi korupsi ini, sektor publik memiliki banyak pekerjaan rumah untuk diselesaikan.

Berdasarkan strategi nasional pencegahan dan pemberantasan korupsi, terdapat 6 strategi utama dalam melawan korupsi salah satu yang disebutkan yaitu melaksanakan upaya-upaya pencegahan (Stranas PPK 2012:23). Sehingga sudah jelas bahwa upaya nyata dalam memberantas korupsi yakni bagaimana masing-masing instansi di sektor publik mampu menginisiasi upaya-upaya pencegahan korupsi di lingkungannya.

Oleh karena itu langkah awal untuk menghadirkan inisiatif pencegahan korupsi dapat kita pinjam lagi pertanyaan pembuka diatas, mengapa orang melakukan korupsi. Pada tahun 1950, jawaban dari pertanyaan tersebut dijawab oleh seorang kriminolog bernama Donald Cressey yang merangkumnya dalam fraud triangle theory. Disebutkan terdapat 3 elemen penting pemicu timbulnya perilaku korup, yaitu: pressure, rationalization, dan opportunity (Quah 2007).

Pressure biasa pula disebut dengan istilah incentives dalam konteks korupsi merupakan tekanan yang dirasakan yang berasal dari lingkungan eksternal yang mendorong seseorang untuk mendapatkan keuntungan tertentu atau dapat pula diartikan sebagai keinginan yang bersumber dari dalam diri seseorang untuk mendapatkan keuntungan finansial (Hasnan et al 2008).

Opportunity atau peluang biasanya muncul karena kurangnya pengawasan atau kurang efektifnya tata kelola organisasi yang mendorong orang untuk melakukan perbuatan curang, Abdullahi et al (2015:33). Rationalization, didefinisikan sebagai cara melegitimasi sebuah perilaku atau konsep yang sebenarnya tidak sesuai dengan kebaikan yang dipercaya oleh orang lain, Slezak (2013).

Dalam melakukan tindakan korup, seseorang akan mempertimbangkan dengan baik (terkadang juga tidak sadar) ketiga variabel terkait manfaat yang akan diterima untuk keputusannya melakukan atau tidak melakukan korupsi (Prabowo, 2014: 318). Dengan kata lain semua variabel ini memiliki hubungan yang saling mempengaruhi (kausalitas). Walaupun ada juga pendapat yang mengatakan tidak harus ada semua variabel pada sebuah kasus korupsi, bahkan hanya hadir satu variabel saja dimungkinkan terjadinya korupsi.

Hasil penelitian dari Tarru, J (2017:92) membuktikan bahwa ketiga variabel tersebut merupakan pemicu tindakan fraud pada 
organisasi publik. Hanya saja perlu pengkajian lebih lanjut untuk mengukur variasi terbaik dari fraud triangle guna menghasilkan proposisi strategi pencegahan korupsi yang optimal bagi Instansi Pelayanan Publik.

Oleh karena itu penelitian ini mencoba untuk meneliti lebih dalam terkait sensitivitas masing-masing variabel dari fraud triangle tersebut. Tujuan dari penelitian ini agar dapat diketahui variabel prioritas sebagai penentu utama untuk mencegah terjadinya perilaku korupsi disebuah instansi publik, dengan cara menguji sensitivitas variabel pressure, rationalization, dan opportunity pada upaya pemberantasan korupsi. Sehingga dapat diusulkan sebuah langkah prioritas pencegahan korupsi yang efektif bagi organisasi publik.

\section{METODE PENELITIAN}

Berdasarkan proses yang dilakukan, penelitian ini bersifat kuantitatif dengan mengadopsi metode survei (Hermawan 2009:19). Data diperoleh dari kuisioner yang telah diisi oleh 47 sampel pegawai pada RSUD Kabupaten Polewali Mandar, di Provinsi Sulawesi Barat. Pengambilan Sampel dilakukan dengan menggunakan teknik non-probability sampling, incidental sampling, (Sugiyono 2015:156).
Sampel yang dipilih tentunya mempertimbangkan keterwakilan profesi dalam rumah sakit, yaitu: tenaga medis, bagian adminstrasi, bagian keuangan, dan bagian perencanaan.

Data yang diperoleh dianalisis menggunakan instrumen statistika, Amos 18 dengan uji Path Analysis (Santoso 2012:199), dengan menganalisis keterkaitan 4 variabel, yaitu: Pressure, Rationalization, Opportunity, dan Pencegahan Korupsi. Variabel Pressure diukur dengan menggunakan indikator penghasilan, beban keuangan tambahan, dan tidak adanya intervensi dalam bekerja.

Variabel Rationalization diukur dengan menggunakan indikator pengembangan karir pegawai, kompetensi pegawai, dan penerapan merit system. Variabel Opportunity diukur dengan menggunakan indikator sistem keuangan berbasis IT, auditor internal, dan adanya sistem pengawasan multi arah.

Sedangkan variabel pencegahan korupsi diukur dengan menggunakan indikator minimnya penyalahgunaan anggaran, kesesuaian penggunaan anggaran, dan prestasi pengelolaan keuangan. 


\section{HASIL PENELITIAN}

1. Model I (Menguji Sensitivitas
Opportunity)

Tabel 1: Measurement Model Test Pada Model I

\begin{tabular}{|c|c|c|c|}
\hline $\begin{array}{c}\text { Chi } \\
\text { Square }\end{array}$ & $\begin{array}{c}\text { Probability } \\
\text { Level }\end{array}$ & $\begin{array}{c}\text { Goodness } \\
\text { of Fit } \\
\text { Index }\end{array}$ & $\begin{array}{c}\text { Root } \\
\text { Mean } \\
\text { Residual }\end{array}$ \\
\hline 14,716 & 0,001 & 0,880 & 0,018 \\
\hline
\end{tabular}

Sumber: Data diolah, 2018

Gambar 2: Kerangka Penelitian Uji Sensitivitas Variabel Opportunity

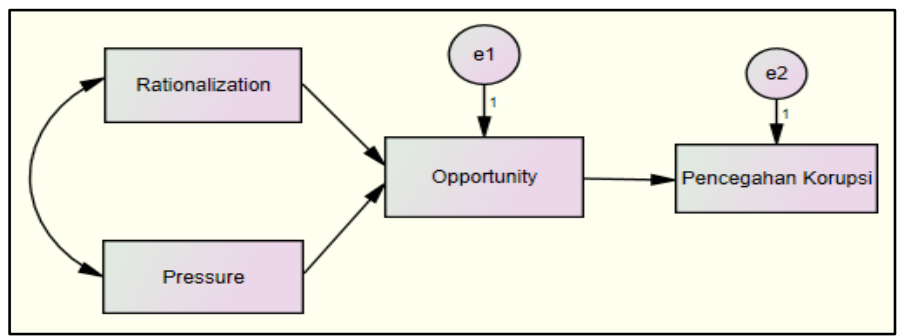

Sumber: Data diolah, 2018

Measurement model test pada tabel 1, memperlihatkan hasil nilai chi square (thitung) sebesar 14,716 yang lebih besar dibandingkan t-tabel, yakni: $\quad 5,99$ menunjukkan model belum fit karena matriks kovarian sampel berbeda dengan matriks kovarian estimasi. Begitupula dengan nilai probability level sebesar 0,001 yang lebih kecil dari 0,05, menunjukkan bahwa model I belum fit dengan data sampel yang ada.

Namun penilaian tersebut sedikit berbeda dengan hasil dari pengujian Goodness of Fit Index (GFI) dengan nilai sebesar 0,880 yang mendekati angka 1 dan nilai Root Mean Residual (RMR) sebesar
0,018 yang lebih kecil dibanding 0,08 menunjukkan model I ini sudah fit.

Tampak pada gambar 2, hasil structural model test untuk model I. Pada model ini terdapat 1 hubungan timbal balik yaitu variabel pressure dan rationalization. Besaran korelasi antar kedua variabel ini yaitu 0,074 artinya memiliki hubungan yang positif atau searah. Sedangkan nilai propability $(P)$ untuk hubungan ini sebesar 0,618 jauh diatas 0,05 sehingga dinyatakan hubungan kedua variabel ini tidak signifikan.

Masih pada gambar 2, nilai korelasi rationalization terhadap opportunity sebesar 0,284 artinya keduanya memiliki hubungan yang positif atau searah. Nilai propability $(P)$ untuk hubungan variabel ini yakni 0,045 lebih kecil dari 0,05 sehingga dinyatakan hubungan keduannya signifikan.

Korelasi antara pressure terhadap opportunity yakni 0,015 artinya terdapat hubungan yang searah walaupun nilainya kecil, sedangkan nilai $P$ untuk hubungan ini sebesar 0,917 lebih besar dibandingkan 0,05 artinya hubungan ini tidak signifikan. Terakhir, hubungan opportunity terhadap pencegahan korupsi. Tampak nilai korelasi untuk hubungan ini 0,062 artinya terdapat hubungan yang searah, sedangkan nilai $P$ sebesar 0,674 yang memiliki arti hubungan ini tidak signifikan. 
2. Model II (Menguji Sensitivitas Rationalization)

Hasil measurement model test pada tabel 2, memperlihatkan nilai chi square (thitung) yaitu 3,681 yang lebih kecil dibandingkan t-tabel, yakni: 5,99 menunjukkan model fit karena matriks kovarian sampel tidak berbeda dengan matriks kovarian estimasi. Begitupula dengan nilai probability level sebesar 0,159 yang lebih besar dari 0,05, menunjukkan bahwa model II telah fit dengan data sampel yang ada. Hasil ini juga diperkuat dengan nilai GFI sebesar 0,963 yang sangat mendekati angka 1 dan nilai RMR sebesar 0,013 yang lebih kecil dibanding 0,08 menunjukkan model II ini sudah fit secara keseluruhan.

Seperti tampak pada gambar 3, hasil structural model test untuk model II. Pada model ini terdapat 1 hubungan timbal balik yaitu variabel opportunity dan pressure. Besaran korelasi antar kedua variabel ini yaitu 0,36 artinya memiliki hubungan yang positif atau searah. Sedangkan nilai propability $(P)$ untuk hubungan ini sebesar 0,809 masih lebih besar dari nilai cut off nya 0,05 sehingga dinyatakan hubungan kedua variabel ini tidak signifikan.
Tabel 2: Measurement Model Test Pada Model II

\begin{tabular}{|c|c|c|c|}
\hline $\begin{array}{c}\text { Chi } \\
\text { Square }\end{array}$ & $\begin{array}{c}\text { Probability } \\
\text { Level }\end{array}$ & $\begin{array}{c}\text { Goodness of } \\
\text { Fit Index }\end{array}$ & $\begin{array}{c}\text { Root Mean } \\
\text { Residual }\end{array}$ \\
\hline 3,681 & 0,159 & 0,963 & 0,013 \\
\hline
\end{tabular}

Sumber: Data diolah, 2018

Gambar 3: Hasil Uji Sensitivitas Variabel Rationalization

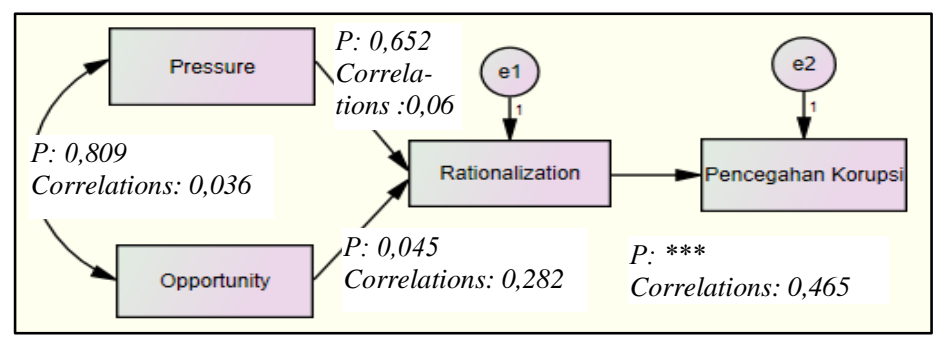

Sumber : Data diolah, 2018

Masih pada gambar 3, nilai korelasi pressure terhadap rationalization sebesar 0,06 artinya keduanya memiliki hubungan yang positif atau searah walaupun nilainya kecil. Nilai propability $(P)$ untuk hubungan variabel ini yakni 0,652 lebih besar dari 0,05 sehingga dinyatakan hubungan keduannya tidak signifikan.

Korelasi antara opportunity terhadap rationalization yakni 0,282 artinya terdapat hubungan yang searah, sedangkan nilai $\mathrm{P}$ untuk hubungan ini sebesar 0,045 lebih kecil dibandingkan 0,05 artinya hubungan ini signifikan. Terakhir, hubungan rationalization terhadap pencegahan korupsi. Tampak nilai korelasi untuk hubungan ini 0,465 artinya terdapat hubungan yang searah, sedangkan nilai $P$ korelasi ini mendekati 
angka nol yang disimbolkan dengan tanda *** yang memiliki arti hubungan ini signifikan.

3. Model III (Menguji Sensitivitas Pressure)

Measurement model test pada tabel 3, menghasilkan nilai chi square (t-hitung) sebesar 11,498 yang lebih besar dibandingkan t-tabel, yakni: 5,99 menunjukkan model belum fit karena matriks kovarian sampel berbeda dengan matriks kovarian estimasi. Begitupula dengan nilai probability level yakni sebesar 0,003 yang lebih kecil dari 0,05, menunjukkan bahwa model III belum fit dengan data sampel yang ada. Namun penilaian tersebut berbeda dengan hasil dari pengujian Goodness of Fit Index (GFI) dengan nilai sebesar 0,900 yang mendekati angka 1 dan nilai RMR sebesar 0,010 yang lebih kecil dibanding 0,08 kedua parameter ini menunjukkan bahwa model III ini sudah fit.

Tampak pada gambar 4, hasil structural model test untuk model III. Pada model ini terdapat 1 hubungan timbal balik yaitu variabel rationalization dan opportunity. Nilai korelasi antar kedua variabel ini yakni 0,285 artinya memiliki hubungan yang positif atau searah. Sedangkan nilai propability $(P)$ untuk hubungan ini sebesar 0,063 berada diatas 0,05 sehingga dinyatakan hubungan kedua variabel ini tidak signifikan.

Tabel 3: Measurement Model Test Pada Model III

\begin{tabular}{|c|c|c|c|}
\hline $\begin{array}{c}\text { Chi } \\
\text { Square }\end{array}$ & $\begin{array}{c}\text { Probability } \\
\text { Level }\end{array}$ & $\begin{array}{c}\text { Goodness of } \\
\text { Fit Index }\end{array}$ & Root Mean Residual \\
\hline 11,498 & 0,003 & 0,900 & 0,010 \\
\hline
\end{tabular}

Sumber: Data diolah, 2018

Gambar 4: Kerangka Penelitian Uji Sensitivitas Variabel

Presssure

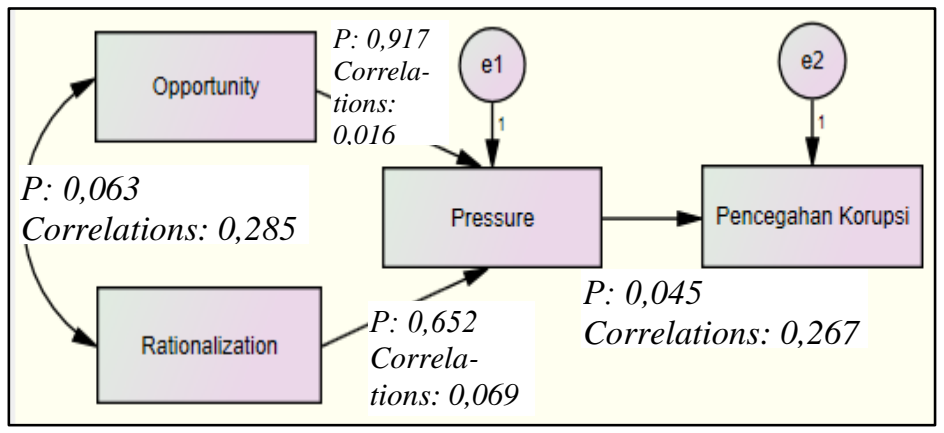

Sumber: Data diolah, 2018

Nilai korelasi variabel opportunity terhadap pressure sebesar 0,016 artinya keduanya memiliki hubungan yang positif atau searah. Nilai propability $(P)$ untuk hubungan variabel ini yakni 0,917 lebih besar dari 0,05 sehingga dinyatakan hubungan keduannya tidak signifikan.

Korelasi antara rationalization terhadap pressure yakni 0,069 artinya terdapat hubungan yang searah walaupun nilainya kecil, sedangkan nilai $P$ untuk hubungan ini sebesar 0,652 lebih besar dibandingkan 0,05 artinya hubungan ini tidak signifikan. Terakhir, hubungan pressure terhadap pencegahan korupsi. Tampak nilai 
korelasi untuk hubungan ini 0,267 artinya terdapat hubungan yang searah, sedangkan nilai $P$ sebesar 0,045 lebih kecil dari 0,05 yang memiliki arti hubungan ini signifikan.

\section{PEMBAHASAN}

1. Komparasi 3 model

Berdasarkan hasil penelitian di atas, terlihat bahwa ketiga model yang ada memiliki hasil yang berbeda-beda. Pada measurement test yang dilakukan untuk menguji derajat fit suatu model. Indikator $c h i$ square pada model I, II dan III berturut-turut sebesar 14,716; 3,681; 11,498 yang memiliki nilai dibawah t-tabel $(5,99)$ yang merupakan model yang fit berarti hanya model II yang memenuhi kriteria ini. Namun perlu juga dicatat bahwa nilai chi square model III masih lebih bagus karena lebih dekat pada 5,99 dibandingkan dengan nilai chi square model I. Hasil yang sama juga diperoleh dengan menggunakan indikator probability level dimana hanya model II yang memenuhi kriteria model fit karena nilainya lebih besar dari 0,05. Walaupun tidak fit dengan menggunakan indikator ini namun model III $(0,003)$ masih lebih bagus dibanding model II $(0,001)$ karena nilainya lebih mendekati 0,05 . Indikator GFI yang diujikan pada ketiga model, terlihat semua model memenuhi kriteria fit karena nilainya semua mendekati 1. Namun jika diurut maka model II memiliki GFI terbesar yaitu 0,963 kemudian diikuti oleh model III $(0,90)$ dan model I (0,88). Indikator terakhir yang digunakan untuk menilai fit nya suatu model yaitu RMR. Hasil yang serupa diperoleh untuk pengujian ini pada semua model dimana semua menunjukkan model yang fit karena nilai yang berada mendekati 1 dan lebih kecil dari 0,08. Hanya saja jika diurut maka model yang paling fit yakni model III $(0,010)$ kemudian diikuti oleh model II $(0,013)$ dan model I $(0,018)$.

Terdapat banyak indikator untuk menilai derajat fit suatu model. Namun, suatu indikator yang menunjukkan model yang fit, belum tentu akan memberikan suatu kesimpulan yang sama apabila menggunakan indikator fit yang lain, masing-masing indikator memiliki kelebihan dan kelemahan (Ghozali, I dan Fuad 2005:29). Sehingga dapat dikatakan ketiga model diatas semuanya bisa digunakan untuk dilakukan structural test untuk melihat korelasi disetiap konstruk yang ada pada model. Namun demikian dari komparasi yang dilakukan di atas, terlihat bahwa model II (model sensitivitas rasionalisasi) yang paling fit diantara model yang ada. Sejalan dengan tujuan penelitian maka dilakukan pemilihan model yang terbaik, sehingga model II ini 
yang akan dianalisis lebih jauh guna menghasilkan rekomendasi penelitian.

2. Model Sensitivitas Rasionalisasi

Hasil path analysis semua konstruk pada semua model menempatkan hubungan antara rasionalisasi dengan pencegahan korupsi sebagai hubungan dengan korelasi yang paling besar nilainya selain itu hubungannya juga signifikan. Ini berarti bahwa upaya rasionalisasi merupakan faktor paling utama bagi koruptor dari dalam memutuskan melakukan tindakan korupsi di instansi publik.

Rasionalisasi merupakan faktor utama terjadinya fraud (Kula et al, 2011). Koruptor di instansi pemerintah pada umumnya melakukan rasionalisasi atas perilaku curangnya dengan beragam bentuk guna membuat mereka merasa tidak bersalah (ACFE, 2014). Bentuk-bentuk rasionalisasi dapat dilakukan dengan beragam cara diantaranya: "saya tidak mengambil uang kantor, hanya pinjam sementara karena akan saya kembalikan"; “organisasi tidak akan tahu, kalau saya mengambil sebagian"; "orang lain tidak tahu apa yang saya lakukan"; "tidak ada yang dirugikan malahan organisasi terbantu"; "saya berhak, karena selama ini organisasi tidak perhatikan saya" (Golden, W.T et al 2006:136).
Rasionalisasi dapat pula dikatakan sebagai jawaban moral/etika yang dibuat seseorang agar merasa nyaman dalam melakukan korupsi (Rae, K \& Subramaniam, N, 2008). Bicara moral, dapat dikaitkan dengan nilai-nilai yang diyakini kebenarannya sebagai pegangan hidup (Bertens 1994:7). Oleh karenanya, sesorang yang memiliki nilai moral yang kuat disaat mengalami tekanan besar, namun memiliki keyakinan bahwa tindakan curangnya dapat membuatnya ditangkap dan dipenjara, memutuskan untuk tidak melakukan korupsi, (Albrecht, W.S et al, 2008). Seseorang dengan nilai etika yang lemah memiliki kecenderungan untuk melakukan korupsi (Chen et al, 2013).

Nilai-nilai etika mendapatkan mulai mendapatkan perhatian yang tinggi setelah terungkapnya mega skandal korupsi yaitu kasus Enron dan Worldcom diawal dekade 2000, yang terungkap setelah berupaya menutup-nutupi ketidakjujuran dalam melaporkan kekayaannya. Belajar dari hal tersebut maka dirasakan sangat penting untuk organisasi pemerintah membangun dan selalu menggelorakan nilai-nilai etika yang menjadi komitmen bersama sebagai langkah preventif dalam mencegah perilaku korup. Walaupun memang realita sering dijumpai bahwa membangun sisi "soft" dari organisasi lebih 
sulit dan kadangkala tidak menarik serta luput dari perhatian, dibandingkan membangun sisi "hard" dari organisasi. Inilah mengapa rasionalisasi merupakan bagian yang terberat untuk diidentifikasi dibandingkan dengan pressure dan opportunity (Golden, W.T et al 2006:57).

Rentang Januari hingga Februari 2018, sesuai press release yang disampaikan oleh KPK sebanyak 15 kasus tindak pidana korupsi telah ditetapkan tersangkanya (www.kpk.go.id). Sebanyak 10 kasus melibatkan pimpinan daerah, Gubernur dan Bupati, 3 kasus melibatkan anggota DPRD kabupaten, 1 kasus melibatkan anggota DPR RI, dan 1 kasus melibatkan pengacara dan seorang dokter. Boleh dikatakan hampir semua dari kasus tersebut melibatkan pemimpin di daerah. Ini merupakan preseden buruk bagi bangsa ini untuk menggelorakan semangat anti korupsi. Jika dikaitkan realita tersebut dengan rasionalisasi, maka rasionalisasi mendapatkan tanah yang subur untuk tumbuh berkembang luas karena ketiadaan keteladanan pemimpin. Contoh rasionalisasi yang dapat muncul dilingkungan pegawai: "saya hanya loyal pada pimpinan, makanya saya berbuat hal tersebut", "pimpinan saja beri contoh", "pimpinan tidak pernah mengerti apa yang sudah kami berikan pada organisasi","pimpinan hanya memikirkan kepentingannya, buat apa saya berprestasi”.

Walaupun memang disadari ketiadaan keteladanan pemimpin bukan saja berimplikasi pada semakin mudahnya orang melakukan rasionalisasi terhadap hal buruk yang dilakukannya. Namun juga berimplikasi pada sulitnya menciptakan tata kelola organisasi yang baik guna menutup opportunity perilaku curang dan menghadirkan suasana kerja nyaman yang menghindarkan pegawai dari tekanan negatif dalam bekerja.

$$
\text { Dari prespektif pemimpin, }
$$
menghadirkan beragam strategi pencegahan korupsi sebenarnya merupakan upaya preventif bagi dirinya sendiri. Banyak kejadian memperlihatkan seorang pemimpin awalnya tidak bermaksud melakukan korupsi namun terperangkap oleh karena sistem kerja yang ada dalam organisasi. Oleh karenanya sudah waktunya bagi pemimpin menjadi pelopor, pengawal, dan pemberi spirit bagi terciptanya terobosan-terobosan yang kreatif guna meningkatkan profesionalisme kerja sekaligus menjadi tonggak pemberantasan korupsi dilingkungan kerjanya masingmasing. Sehingga tepatlah yang dikatakan oleh Ki Hadjar Dewantara: Ing Ngarsa Sung Tulada, Ing Madya Mangun Karsa, Tut Wuri Handayani (Wiryopranoto et al 2017:34) 
Selanjutnya perlu dianalisis sesuai temuan ini, mengapa orang melakukan rasionalisasi? berarti ada yang melatarbelakanginya. Berdasarkan model II ini maka kita dapat memecahnya kedalam 2 pemikiran, yaitu:

\section{a. Pressure $\rightarrow \quad$ Opportunity \\ $\rightarrow$ Rationalization $\rightarrow$ Pencegahan}

Korupsi

Pressure yang tinggi membuat orang berpikir untuk mencari kesempatan. Setelah mendapatkan peluang melakukan rasionalisasi alias pembenaran untuk atau atas perilaku korupnya. Pressure dapat saja bersumber dari dalam diri seseorang, pekerjaan, maupun lingkungan eksternal dalam kaitan dengan keuangan maupun yang bukan keuangan, (Kassem, R and Higson, A, 2012). Opportunity atau kesempatan bisa terjadi apabila tidak ada pengawasan yang baik untuk mencegah perilaku curang, susahnya mengakses informasi, serta kepemimpinan yang lemah (Albrecht et al, 2008).

Hasil diatas sesuai dengan penelitian dari Lister (2007) yang menyebutkan bahwa pressure merupakan pemicu awal tindakan korup. Opportunity kemudian diibaratkan sebagai minyak yang membuat api tetap menyala (the fuel that keeps the fire going), sedangkan rasionalisasi sebagai oksigen yang membuat api tetap membakar (the oxygen that keeps the fire burning).

Serupa dengan penelitian dari Wilson (2006) yang mengungkapkan bahwa pressure merupakan motivasi dalam melakukan perbuatan curang, opportunity merupakan kemampuan mengatasi pengawasan organisasi, dan rationalizaition sebagai jawaban moral/etika dalam membenarkan perilaku buruk tersebut.

Selain hubungan rasionalisasi terhadap pencegahan korupsi, hubungan opportunity terhadap rasionalisasi juga memiliki hubungan korelasi positif yang signifikan. Ini memberi pesan pentingnya organisasi sektor publik menciptakan kondisi kerja yang kondusif sehingga peluang melakukan korupsi dapat dihindari. Sebagaimana penelitian dari Hooper et al (2010), menyebutkan bahwa walaupun terdapat tekanan yang besar, korupsi tidak akan terjadi kecuali terdapat peluang dalam instansi. Artinya sepanjang tata kelola dalam organisasi baik seperti pengelolaan keuangan yang transparan, sistem audit yang baik hadir dalam institusi maka potensi terjadinya korupsi dapat dihindari. Namun memang diperlukan komitmen yang kuat seluruh elemen organisasi untuk bersama melakukan terobosan, bukan sekedar bussiness as usual. 
Pandangan ini diperkuat dengan pendapat bahwa jika tingkat efektivitas tata kelola organisasi tinggi maka tingkat korupsi relatif rendah, untuk menghadirkan tata kelola tersebut dibutuhkan kreativitas, (Hardjapamekas, 2017).

\section{b. Opportunity $\rightarrow$ Pressure $\rightarrow$ Rationalization $\rightarrow$ Pencegahan Korupsi}

Opportunity yang besar membuat orang semakin termotivasi untuk bertindak curang. Sebagaimana diketahui pressure merupakan sumber motivasi orang untuk melakukan korupsi datangnya tidak harus dari dalam diri pelaku, namun juga berasal dari lingkungan eksternal.

Pressure yang besar dapat membuat orang untuk mudah melakukan rasionalisasi. Seseorang dengan potensi insentif yang dapat diraihnya akan melakukan tindakan korupsi walaupun tidak ada peluang untuk hal tersebut, sebagaimana dikutip pada Golden, W.T et al (2006:136):

"...all three conditions of the fraud triangle will be present in varying degrees when fraud occurs. They are closely related. When the incentive to commit fraud is strong, it is likely to be easier for perpetrators to rationalize their actions. Easy opportunity may have a similar effect: when internal controls are absent or ineffective, an employee may conclude that management is indifferent to fraud..."

\section{KESIMPULAN DAN SARAN}

Berdasarkan pembahasan di atas, sebagai upaya pemberantasan korupsi di Sektor Publik disimpulkan: 1. Rasionalisasi merupakan faktor utama terjadinya perilaku korup di instansi publik. Sehingga langkah prioritas awal dalam memberantas korupsi yakni, meminimalkan bahkan menghilangkan potensi terjadinya rasionalisasi dikalangan pegawai. Caranya dengan membangun nilai-nilai etika yang dipatuhi dan dipraktekkan oleh segenap elemen organisasi. Selain itu keteladanan harus ditampakkan khususnya oleh pemimpin di organisasi, pemimpin harus memberikan contoh perilaku yang baik. 2 . Opportunity memiliki pengaruh yang signifikan atas terjadinya rasionalisasi. Oleh karena itu sangat penting bagi organisasi membuat langkah preventif dengan menutup kesempatan orang untuk melakukan korupsi. Untuk itu perlu dihadirkan sistem kerja yang transparan, akuntabel, tidak berbelit-belit, ada sistem pengawasan yang efektif. Sekali lagi peran pemimpin birokrasi sangat diperlukan untuk mempelopori dan mengawal hadirnya pengelolaan organisasi publik yang profesional. Semakin institusi pelayanan publik profesional dalam melayani maka semakin kuatlah institusi tersebut 
dalam mencegah terjadinya korupsi diinstansinya.

Saran bagi penelitian selanjutnya, dapat mengembangkan model sensitivitas rasionalisasi dengan mengukur hubungan tidak langsung masing-masing variabel terhadap upaya pemberantasan korupsi sehingga lebih representatif hasilnya. Selain itu pada model juga dapat memasukkan unsur kepemimpinan dan nilai-nilai etika didalamnya, sehingga model semakin komprehensif dalam tinjauannya.

\section{REFERENSI}

\section{a. Buku}

Ali, Mahrus. 2013. Hukum Pidana Korupsi. Cetakan pertama. Yogyakarta: UII Press Yogyakarta.

Bertens, K. 1994. Etika. Cetakan Kedua. Jakarta: Gramedia.

Ghozali, I \& Fuad. 2005. Structural Equation Modeling: Teori, Konsep \& Aplikasi Dengan Program Lisrel 8.54. Semarang: Badan Penerbit Universitas Diponegoro.

Golden, T.W., Skalak, S.L \& Clayton, M.M. 2006. A Guide To Forensic Accounting Investigation. John Wiley \& Sons INC.

Hermawan, Asep. 2009. Penelitian Bisnis: Paradigma Kuantitatif. Cetakan Kedua. Jakarta: Gramedia Widiasarana Indonesia.

KPK. 2015. Renstra KPK 2015-2019.
Santoso, S. 2012. Analisis SEM Menggunakan AMOS. Jakarta: Elex Media Komputindo.

Sugiyono. 2015. Metode Penelitian Manajemen. Cetakan keempat. Bandung: Alfabeta.

Wiryopranoto, S., Herlina, N., Marihandono, D \& Tangkilisan, Y.B. 2017. Perjuangan Ki Hajar Dewantara: Dari Politik ke Pendidikan. Jakarta: Museum Kebangkitan Nasional Direktorat Jenderal Kebudayaan Kementerian Pendidikan dan Kebudayaan.

.. 2012. Strategi Nasional Pencegahan \& Pemberantasan Korupsi.

\section{b. Jurnal}

Abdullahi, R., Mansor, N \& Shahir Nuhu, M. 2015. Fraud Triangle Theory and Fraud Diamond Theory: Understanding the Convergent and Divergent for Future Research. European Journal of Business and Management. Vol 7, No.28. p 30-37.

Albrecht, W.S., Albrecht, C \& Albrecht, C.C. 2008. Current Trends in Fraud and Its Detection: A Global Perspective. Information Security Journal. Vol. 17.

Chen, J.D., Hou, W \& Lee, E. 2013. Executive Integrity, Audit Opinion, and Fraud in Chinese Listed Firms. Emerging Markets Review. 15. p 7291.

Hooper, M.J \& Pornelli, C.M. 2010. Dettering and Detecting Financial Fraud: A Platform for Action.

Kassem, R \& Higson, A. 2012. The New Fraud Triangle Model. Journal of Emerging Trends in Economics and 
Management Sciences. 3 (3). p 191195.

Kula, V., Yilmaz, C., Kaynar, B \& Kaymaz, A.R. 2011. Managerial Assessment of Employee Fraud Risk Factors Relating to Misstatement Arising From Misappropriation of Assets: A Survey of ISE Companies. International Journal of Business and Social Science. 2(23). p 171-180.

Lister, L.M. 2007. A Practical Approach to Fraud Risk. Internal Auditor. December. p 1-30

Prabowo, H. Y. 2014. To Be Corrupt Or Not To Be Corrupt. Journal of Money Laundering Control. Vol.17 No.3. p 306-326.

Quah, ST Jon. 2007. Combating Corruption Singapore-Style: Lessons for Other Asian Countries. Maryland Series in Contemporary Asian Studies. Number. 2 - 2007 (189).

Rae, K \& Subramaniam, N. 2008. Quality of Internal Control Procedures: Antecedents and Moderating Effect on Organisational Justice and Employee Fraud. Managerial Auditing Journal. 23 (2). p 104-124.

Tarru, J. 2017. Pencegahan Korupsi di Instansi Pelayanan Publik: Studi Kasus Rumah Sakit Umum Daerah Kabupaten Majene Provinsi Sulawesi Barat. Jurnal Ilmiah Administrasi Publik. Vol. XIII No. 1. p 85-93.

Wilson, I. 2006. Regulatory and Institutional Challenges of Corporate Governance in Nigeria Post Banking Consilidation. Nigerian Economic Summit Group (NESG) Economic Indicators. April June. Vol. 12 No. 2.

\section{c. Jurnal Elektronik}

Hasnan, S., Abdul Rahman, R \& Mahenthrian, S. 2008. Management Predisposition, Motive, Opportunity, and Earnings Management for Fraudalent Financial Reporting in Malaysia. https://papers.ssrn.com/sol3/papers.cfm ?abstract_id=1321455

\section{d. Makalah, Paper, atau Orasi Ilmiah.}

Association of Certified Examiner (ACFE). 2014. Report to the Nations on Occupational Fraud and Abuse: 2014 Fraud Study. ICFE Publisher. https://www.acfe.com/rttn/docs/2014report-to-nations.pdf

Hardjapamekas, E.R. 2017. Tantangan Governansi dalam Menyelesaikan Masalah Korupsi di Sektor Publik dan Sektor Swasta. Orasi Ilmiah, Fakultas Ilmu Administrasi Universitas Indonesia. Jakarta, 31 Maret 2017.

\section{e. Disertasi}

Slezak, K. 2013. Fraud Prevention and Employee Rationalization in New York State Public Schools. PhD Dissertation. Department of Educational Administration and Policy Studies University at Albany, New York. 
Johann Tarru/Jurnal Administrasi Negara, Volume 24 Nomor 1 (2018)/ 1-16 